\title{
When We Motated off the Face of the Earth Lizabeth Carpenter
}

THE SUMMER OF THE YEAR we motated off the earth, my husband's bicycle was broken. He took this pretty well, considering - not six months before - he was almost strangled into silence by his own nerves, shot to pieces and aimless. He was not a person driven to grab whatever gusto he could get (especially if this bothered the neighbors), to win friends, or to influence anyone, really. For no good reason he didn't fit on this planet. He couldn't make himself fit in. He could no longer say what his dreams were-or what they had been.

Did you ever dream you could fly? The day we motated off the face of the earth was like that. In dreams (or was this real?) I have pushed off from the bottom of the ocean and floated up through the quilted buoyant blue, feet like wings on the pedals, powering me-us-forward.

Two spokes and a piece of flange had broken off the rear axle of my husband's bicycle and there we were, on the far side of Wyoming, the closest bike dealer three hundred miles away. Ahead of me my husband's sweaty, hunkered-down back (the color of wet wood with tiny freckles on each shoulder) had pulled my bicycle in its draft, a pull stronger than I could explain. On the east side of the Wind River Range a hawk shrieked from somewhere over the ridge. A herd of antelope like chess pieces grazed below the rocks fifty yards from the highway.

Going uphill, of course, you must do your own work. There's not much draft at that slow a pace. His rear wheel wobbles, though with our spoke wrench we have trued it as best we can. We've released the rear brake so the wobbly tire doesn't rub. We have repacked the bulk of his load onto my bike: tools, tent, extra water. Still, he does not feel safe.

Once over the top and descending, his big back blocks the wind and pulls me along like music. From the mountains to the prairies to the oceans white with foam, I'm a steamroller, baby, I'm gonna roll all over you, this land is your land, they call the wind Mariah. The wind sears our eyes inside our sunglasses; tears dry on our cheeks. Naturally my husband must apply his brakes. 
I flew down the Wind River Range in his wake. Then I surged ahead, this was inevitable. "See you on the Montana Flats!" I hollered. Just like that, I kicked him out of the house.

II

This left me-you can imagine-way, way out there, riding solo.

My husband's image remained, however, in the little rearview mirror that protrudes from my sunglasses. He could have crashed at any moment. I coasted out of the trees, around a horseshoe switchback, slowed a bit. He was never out of sight for long, though he was shrinking. He was shrinking. "And you thought I was aimless!" he shouted, his voice faint but clear. "Is a dull flower aimless? A piece of sand? And do you consider children aimless, too?"

We were no longer coasting but faced a Wyoming headwind like the cost of health insurance. And then, out of the blue, I made a decision. I rose in the saddle as tall - nearly - as him, settled my bike comfortably in front of his. He would have no doubt wanted me back there behind him, one eye on his broken flange; but I ask you: Where would I be most efficient? How might I be of real service here? When we rode we rode together, with me drafting out of Wyoming, then trading off through the magic northwest native country-Yellow Stone, Black Foot, Bitter Root, Flat Head, Beaver Head, Sand Point, Liberty Bell. We coasted out of the Cascades and on to the islands, finally motating together off the face of the earth. 